\title{
Measures and Distribution of Financial Inclusion in Kenya
}

\author{
Isaac Mwangi \\ Research and Policy Analysis Department, Central Bank of Kenya, \\ PO Box 60000-00200 Nairobi, Kenya
}

\begin{abstract}
This paper interrogates various measures and definitions of financial inclusion (FI) and their cumulative distribution in Kenya. Lack of a substantive and reliable measure of FI hampers the formulation of evidence based policy interventions. The paper presents three measures of FI founded on formal usage of; transactionary, credit, savings/investments and insurance/pension products. The first measure is focused on the use of atleast one formal financial product from each category, the second measure develops a composite measure (index of Financial Inclusion (IFI)) aggregated from the single measures and lastly a use case measure based on the needs framework. From the single product measure; transactionary, credit, savings and insurance, uptake in 2019 averaged 79 percent, 17 percent, 53 percent and 29 percent respectively. The cumulative distribution curves revealed a strong stochastic dominance by the Nairobi sub region. A ranking of the sub regions using the IFI placed Nairobi sub region on top followed by Central and Mombasa in that order. Upper Eastern, North Eastern and North Rift sub regions took the bottom three positions. The paper recommends a sustained campaign to boost the uptake of financial services from the formal strand and particularly credit and insurance whose uptake is relatively low. The study also recommends a shift from the conventional measurement of FI based on product usage to the needs based framework founded on the use case to assess efficacy of formal financial solutions to manage liquidity, mitigate risks and manage future goals.
\end{abstract}

JEL Classification Numbers: C43, C81, G02, G21, G23

Keywords: Financial Inclusion, stochastic dominance, sub region

DOI: $10.7176 / \mathrm{EJBM} / 11-22-07$

Publication date: August $31^{\text {st }} 2019$

\section{Introduction}

A composite index of financial inclusion (IFI) aggregates multiple dimensions of financial inclusion (FI) into a single measure for effective policy formulation. In the context of the IFI generation, holders of a wide range of financial services are considered to be highly financially included as compared to holders of a single financial product (Collins, Murdoch, Rutherford, and Ruthven, 2009). Kenya's IFI was constructed using Kenya's FinAccess survey data following Sarma (2008) formula.

Recent years have witnessed a surging interest in the measurement and determination of FI in the global scene. Lack of a consensus on the definition and standard of measuring FI hampers the management of transitory changes in income through building of buffer stocks (AFI, 2011). FI benefits lower segments of the population by pulling them within the ambit of the formal financial system. Government and policy makers rely on FI indicators to set national targets and strategies to achieve them. Uptake of financial services in Sub Saharan Africa remains low (34.2 percent) compared to the developed world where FI exceeds 90 percent (World Bank, 2014). This point to a 65.8 percent departure from the much touted universal access partly associated with low demand rather than inadequate access to financial services (World Bank (2015). The number of formal accounts among adults, account for 41 percent (24 percent in sub Saharan Africa) against a global target of 90 percent and 89 percent for developing and developed countries respectively (Demirguc-Kunt and Klapper, 2012). This discrepancy creates two reinforcing inequities for the poor. First it limits their financial strength to improve wellbeing through participation in financial markets and second, it aggravates the marginalization of the poor from the formal economy ${ }^{1}$.

Prior to the establishment of the Financial Inclusion Data Working Group (FIDWG) by the Global Partnership for Financial Inclusion (2011) and the Alliance for Financial Inclusion (AFI) to harmonize the collection of the core set of FI indicators, countries adopted different approaches based on their level of financial sophistication (FSD, 2011). Amidzic et al (2014) cites robust measurement of FI as an outstanding challenge. Despite being sensitive to geographical sampling and number of dimensions included, the IFI provides a better approximation of usage which can be improved on as more data is availed (Chakrabarty, 2014; Honohan, 2008).

Claessens (2006) expounds on the measurement of the access dimension using availability of financial services, cost, range type and quality of financial services as well as reliability, convenience, continuity and flexibility of financial services. Determination of bankedness is based on the revealed use rather than access. FI in Kenya grew from 25 percent in 2006 to 83 percent in 2019 (CBK, KNBS \& FSD, 2019). Aggregated measures however risk masking significant exclusion of finance at both individual and regional levels. This led to a construction of both single and composite measures of financial inclusion to map and compare the cumulative

\footnotetext{
${ }^{1}$ Dan Radcliffe and Rodger Voorhies, Bill \& Melinda Gates Foundation1 (2012). A digital pathway to financial inclusion
} 
distributions both inter-temporally and spatially in order to draw an ordinal assessment of the changes and the relative degree of financial inclusion among population subgroups.

The rest of the paper is organized as follows; Section two looks at the review of current literature. Section three outlines the research framework and data used. Section four presents the measures of financial inclusion and lastly section five provides the conclusions and policy recommendations.

\section{Literature Review \\ 2.1 Theoretical Literature}

Financial inclusion and financial development manifest the 'chicken and egg' problem (Sen, 1981). This justifies the imposition of financial development theories in studies on FI. Raza et al. (2014) presents size, depth, access, efficiency and stability of the financial system as some of the indicators of financial development. Measurement of usage of financial services borrows heavily from the classical theory and the modern measurement theories. Classical theory of measurement by Campbell (1953) argues that measurement entail assignment of numbers to represent properties based on physical laws discovered through the derived measurement processes. While challenging Campbell (1953) definition of measurement, Stevens (1959) provided a broader definition linking measurement to the assignment of numerals to objects on the basis of predefined rules now popularly known as the modern measurement theory by Abdel-Magid (1979). Measurement however presupposes what is to be measured hence one must in the first place know what needs measurement.

One other theoretical strand used to motivate measurement of financial inclusion is theory of banking and intermediation. Financial intermediation theories provide means through which financial services flow from the surplus units to the deficit units. Philippon (2015) raises three key financial intermediation considerations which include; measurement of the income of financial intermediaries, definition and construction of the quantity of the intermediated asset and computation of the unit cost of intermediation and quality adjustments. Greenwood and Jovanovic (1990) contends that financial intermediaries facilitate migration of funds to areas where social returns are higher.

The theory of social inclusion also plays a key role in the measurement of financial inclusion by promoting inclusion of all into the financial system, equally and without discrimination. Social inclusion theory is founded on; social bases of collective action, risk management, legitimacy of change processes and inequality and exclusion. The foundations of effective institutions are governed by the expanded sense of 'we' plus the social norms and an inclusive social structure (Woolcock, 2013). Social inclusion therefore provides the capability to maximize one's welfare from access to a wide array of financial services.

Lindbeck and Snower (2001) insiders' outsider model bends on the notion of economic inclusion. It explains why some economic agents in the market enjoy more privileges than others leading to observable disparities in the degree of FI in financial markets. Insiders command a higher economic rent or surplus as compared to outsiders. Lastly, legal structures govern the design of financial products. Strong institutions for protecting and matching investor needs enhance financial development (Porta, 1997; 1998). The existing legal framework in the financial sector governs the establishment of financial sector regulators as well as the formulation of prudential guidelines. This includes deciding on the dimensions of FI to consider and the products classified as formal.

\subsection{Empirical Literature}

Lack of a composite measure of FI limits understanding of the complex nature of FI as well as the link between FI and welfare outcomes. Measurement of FI requires a multidimensional approach to aggregate information from several dimensions. The multidimensional approach was used in constructing the Ease of Doing Business Index (Doing Business 2012), the Human Development Index (HDI), Multidimensional Poverty Index (MPI), Gender Inequality Index (GII) by the United Nations Development Programme (UNDP) and Sarma (2008) and Chakravarty (2010) FI index.

The Global Partnership for Financial Inclusion (CGAP) established by G20 has helped develop basic and secondary indicators of FI based on access, usage, quality and impact dimensions. These include; payments, savings, remittances, insurance and point of sale. The International Monetary Fund (IMF) has also intensified the collection of supply side indicators in its Financial Access Surveys (FAS) at the global front to enhance comparability of access and usage indicators among households and non-financial corporation's across countries.

FAS indicators are collected from financial sector regulators and currently stand at 47 indicators from both geographical and usage dimensions in 189 countries (IMF, 2015). The core set of FI indicators by AFI provided a first attempt at generating a common measurement of FI based on basic and fundamental aspects to enhance the dimensions of access and usage (AFI, 2011). AFI (2011) indicates that the dimensions of access and usage are different in that individuals may opt not to use the financial services despite their availability due to socioeconomic reasons, costs among others.

World Bank's Development Research Group spearheaded the Global Financial Inclusion Index (Global Findex) to fill the data gap on the financial inclusion landscape. This initiative led to the creation of the first 
comprehensive demand side FI indicators based on financial product usage. The data is considered to be rich in enhancing cross country comparability, demographic covariates and tracking countries (148) performance over time on the core set of indicators namely bank accounts, savings, borrowing, payments and insurance (Demirguc Kunt \& Klapper, 2012).

Aduda and Kalunda (2012) in review of theoretical and empirical literature on FI and financial stability reinforced the pivotal role played by FI in enhancing financial development. Although the authors provided the status of FI in Kenya they failed to construct a composite measure of financial inclusion from the portfolio of financial services.

Besides literature on measurement of FI developed by Chakravarty and Pal (2010) and Sarma (2008), newer literature touching on measurement at both micro and macro levels has been developed by; Sarma and Pias (2011) and Amidzic et al. (2014) using factor analysis and Park and Mercado (2015). Chakravarty and Pal (2013) described FI as the delivery of financial services to its people. The domain of financial services is considered to be very huge and varies from one country to another. Based on a sample of sub-National regions (17 states) in India between 1972 and 2009, the authors applied the human development index (HDI) to aggregate six dimensions; geographic penetration demographic penetration; deposit accounts per 1000 people; credit account per 1000 people; deposit income ratio and credit income ratio into a single index of FI. The index of FI increased with the number of households using institutional credits

Honohan (2005) argues that broadly, two main approaches exist where usage of financial services is derived either from household survey data or from inferences drawn on the use of intermediary accounts from existing data. Percentage ownership of a bank account from a formal financial intermediary among adults is the most commonly used indicator of FI (World Bank, 2005). This indicator is however criticized due to its inability to determine the distinct and active accounts in a case where individuals hold multiple accounts (Honohan, 2008). This raises the need to consolidate the multiple accounts to match the number of individuals with accounts. A nonlinear aggregation of loan and transactionary deposit accounts is closely correlated with household usage of financial services (Honohan, 2008). The only challenge is that use of the two dimensions rocks out the role of savings and investments as well as insurance and pension.

Use of single indicators to measure FI has been challenged by Sarma (2008) due to their inability to inform on the extent of FI as evidenced by the Indian case where usage of financial services remained high despite a low density of bank branches. A similar picture was observed in Russia which ranked highest on the usage of bank accounts per 1000 adults despite having a lower bank branch density per 100,000 adults as compared to Thailand, Malaysia and Colombia. Albania also ranked $4^{\text {th }}$ in terms of loan income ratio but $85^{\text {th }}$ in terms of bank branches per 100,000 adults in Beck et al., (2007). Single measures therefore provide an incomplete picture of the level of inclusivity in the entire financial system.

Sarma (2008) recommends the use of a composite index to measure the level of FI based on a combination of various banking sector indicators. The composite index (IFI) which lies between 1 (complete financial inclusion) and 0 (complete financial exclusion applies a three dimensional approach on macroeconomic data based on banking sector outreach to capture accessibility, availability and usage. Accessibility proxied using bank penetration is measured using the number of bank accounts per 1000 adult population with a -1 weight. The number of bank branches and ATMs per 100,000 adult population measures availability, while the ratio of credit plus deposit to GDP measured usage with each of the dimensions carrying a 0.5 weight.

Using an econometric technique, Honohan (2008) developed a composite cross country FI index based on 160 countries. The main focus was on the use of formal financial intermediaries proxied by the use of services from the formal access channel in this context. Given that certain countries had no household survey data to provide the percentage uptake of bank accounts, an alternative estimation technique was used to estimate the number of bank accounts.

Amidzic et al (2014) applied a geometric mean approach to construct an index of FI based on the dimensions of outreach, usage and quality. Key considerations included; geographic and demographic penetration, deposit and lending, dispute resolution, disclosure requirement and cost of usage. The constructed composite index was later used to rank countries hence offering an additional tool for surveillance and policy. The number of ATM machines and bank branches indicators rescaled by land mass and adult population were used. Measurement of usage was based on the percentage of adults with atleast one type of regulated deposit/loan account. However, the index generation ignored quality indicators due to data limitations.

Demirguc-kunt et al., (2015) posited that measurement of financial inclusion helps in identifying opportunities to remove the barriers to financial access. The authors confirmed that FI is centered on usage rather than access. Their findings established that by 2014, 62 percent of adults globally enjoyed holding an account in a bank or other financial institution or with a mobile money provider up from 51 percent in 2011 . This increase in the number of accounts held was attributed to innovations in technology and particularly mobile money especially in developing countries. They also mentioned the huge potential to raise FI among women and the poor. In addition, the authors argued that holding a bank account is not enough; rather, government and private sector should 
strengthen FI by channeling wages through the accounts as opposed to cash payments. Account usage could also be spurred by digitizing payments such as utility bills and school fees which largely relied on cash.

\subsection{Overview of literature}

Literature on FI lacks a universally acceptable, comprehensive measure which can be relied upon in drawing a comparative analysis across cross sections. The urge to measure FI is motivated by Claessens (2006) argument that the profile of a household with a credit facility differs from that of a household with a savings or bank account. Although single measures such as loan and transactionary account usage are critical in the assessment of FI, it's equally important to incorporate the portfolio product usage concept which characterizes the modern day consumer. Amidzic et al., (2014) reliance on the percentage of regulated deposit and loan accounts to proxy the usage dimension locked out savings and investment as well as insurance and pension products which could offer a richer measure of usage.

On the other hand, Demirguc Kunt and Klapper, 2013; Hannig and Jansen, 2010 FI measures focused on single product measures such as; ownership of an account, saving or loan product. A household using more than one financial product is considered to be more sophisticated financially. This notion forms the basis of the author's aggregation of the four financial products; transactionary, credit, savings and insurance using cross sectional data. As to the sufficiency of the usage dimension, Honohan (2008) contends that a non linear aggregation of loan products and transactionary deposit accounts from household surveys exhibit a high correlation with usage of financial services. This study extends this line of thought by including indicators of savings/investment product usage from prudentially regulated financial institutions.

The first attempt at measuring FI is attributed to Beck et al., (2005) using the dimensions of physical access, affordability and eligibility to inform on banking sector outreach. This was later followed by indices of FI developed by Sarma (2008), Honohan (2008), Chakravarty and Pal (2013), Sarma (2012), Amidzic et al., (2014) among others. Sarma (2008) formulae offer a unique reference point in the index construction. The framework is considered to be superior due to the ease of aggregating sub indices from various dimensions.

\section{Method and Data}

In terms of methodology, the IFI measure borrows heavily from leading scholarly work by Sarma $(2008 ; 2012)$, Chakravarty \& Pal (2013) and Amidzic et al. (2014) three step procedure; normalization of indicators, determination of sub indices for each dimension and aggregation of the sub indices. We assumed that the financial system has $k \geq 1$ dimensional activities drawn from transactionary, credit, savings and insurance. One's financial sophistication is evidenced by the number of financial instruments chosen rationally (Collins, Murdoch,

Rutherford, and Ruthven, 2009). The attained FI level from each dimension is denoted by $x_{i}$ whose lower and upper bounds are defined by $m_{i}$ and $M_{i}$, that is, $x_{i} \in\left[m_{i}, M_{i}\right]$. Functioning $i$ is represented by a real valued function $A\left(x_{i}, m_{i}, M_{i}\right)$, which is continuous in its arguments and associated with each $x_{i}\left[m_{i}, M_{i}\right]$. Its difference from the real valued function $\left(1-A_{r}\right)$ yields the shortfall from the actual value of the index. The index of FI (IFI) is derived from the averaging of the individual indicators.

The normalization process is expressed as follows;

$$
n x_{k i}=\frac{x_{k i}}{M_{k}}
$$

where; $x_{k i}$ is the raw value of the kth indicator for individual $\mathrm{i}, \mathrm{Mk}$ the maximum possible value of the indicator across cross sections while nxki is the normalized value of the indicator.

While Sarma (2008) emphasize the need to incorporate the dimensions of usage, availability and access in developing the FI index, paying close attention to each dimension is critical in enhancing consistency prior to aggregation. The construction of the IFI in this paper departs from Sarma (2008) in the following ways. First, aggregation is done only on the basis of the usage dimension (transactionary, credit, savings \& investments and insurance $\&$ pension products). Second, indicators of usage are generated from all formal financial intermediaries rather than bank alone. This nonlinear aggregation targeted the number of financial products used in each category under the formal strand. This approach also differs slightly from Amidzic et al. (2014) which applied factor analysis to generate the IFI excluding insurance services. Chakravarty and Pal (2013) index also differs from Sarma (2008) in that the magnitude of the indicator does not necessarily imply proximity to the ideal state. Although indices come with a fair share of limitations, assessing the performance of the entire financial system can only be done using a composite index. 
The applied formula from Sarma (2008) is expressed as follows;

$$
F I=1-\frac{\sqrt{\sum_{k=1}^{j}\left(\left(M_{k}-x_{k}\right) /\left(M_{k}-m\right)\right)^{2}}}{\sqrt{j}}
$$

where; $\mathrm{Mk}$ is as earlier defined (upper bound), $\mathrm{m}$ the lower bound, $\mathrm{k}$ the number of dimensions under investigation. The ratio $\left(M_{k}-x_{k}\right) /\left(M_{k}-m\right)$ yields the shortfall from the maximum possible value. Once the index is generated, a ranking of all counties in Kenya is done to inform on disparities of FI across the country.

The study relied on the five FinAccess household survey datasets (2006, 2009, 2013, 2016 and 2019). To understand the recent developments in the financial sector, both single and composite measures were used to compare the uptake of financial services in 2016 and 2019 while a trend analysis was done since 2006. The needs based framework was used to test the efficacy of formal financial solutions in managing liquidity, mitigating risks and managing future goals.

\subsection{Stochastic Dominance Testing}

Stochastic Dominance (SD) is a concept applied in decision theory when confronted with a choice between two phenomena (Bawa, 1982). It presents a stochastic ordering of possible outcomes in a probability distribution based on individual preferences. The Kolmogorov-Smirnov (KS) SD test provides a comparative analysis of two cumulative frequency distributions at a time. Chakravarty, Laha and Roy (1967) argue that KS test helps decide if a sample was drawn from a population with a specific distribution. The first order stochastic dominance (FOSD) test provides a comparative analysis of the different cumulative distribution functions of the IFI. The distribution $F($.$) is said to first-order stochastically dominate distribution G($.$) if, for every non-decreasing function$ $u: R \rightarrow R$. we have $\int u(x) d F(x) \geq \int u(x) d G(x)$ and $F(x) \leq G(x)$ for all x (Mas-Colell, Whinston and Green, 1995).

Where two CDF lines cross each other in the FOSD, there arises a need to conduct second order stochastic dominance (SOSD) test to generate the IFI deficit curve where an integral function is drawn on the CDF up to every IFI value.

\section{Fig 3.1 Conceptual Framework}

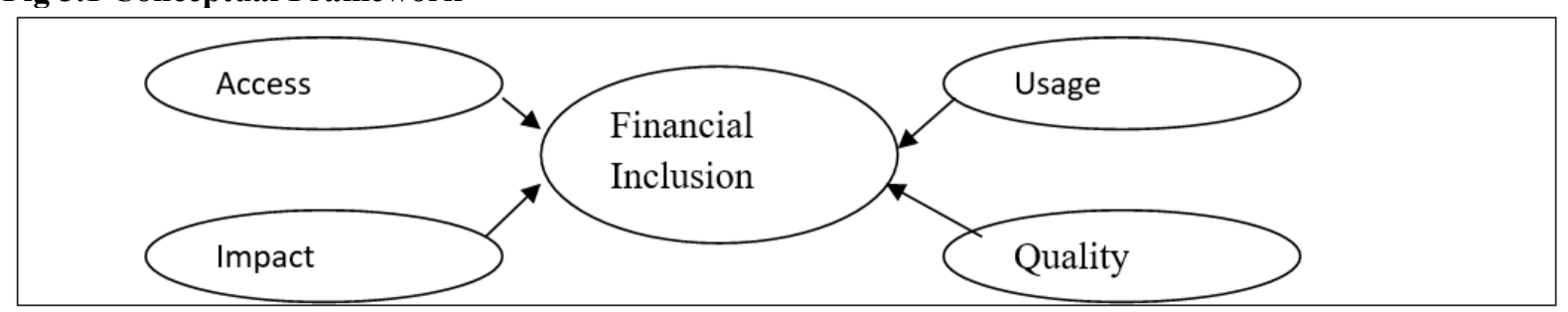

Source: Author, 2019

FI is often categorized along the following dimensions; access, usage, quality and impact (Hannig and Jansen, 2010). The access dimension focuses on proximity to financial services while the usage dimension captures the interaction with various financial services from the demand side. The impact dimension extends this further by assessing how access to and usage of financial services affects people's livelihoods. The quality dimension interrogates features that characterize specific financial products and services (Fig 3.1).

\section{Key Findings}

The discussion is based on both single measures of FI (transactionary, credit, savings and investment, insurance and pension) and the IFI composite measure. In addition, the study introduces a third measure of financial inclusion based on the needs based framework to inform on the effectiveness of formal financial devices. Appendix Table 4.1 which focused on the correlation coefficients for the measures of FI ruled out the presence of perfect multicollinearity.

\subsection{Single Product Measures}

This section concentrates on the formal strand and its components drawn from single measures; transactionary. Credit, savings and investments and insurance and pension products. 
Fig. 4.1 Financial Inclusion Trends: Access vs Usage

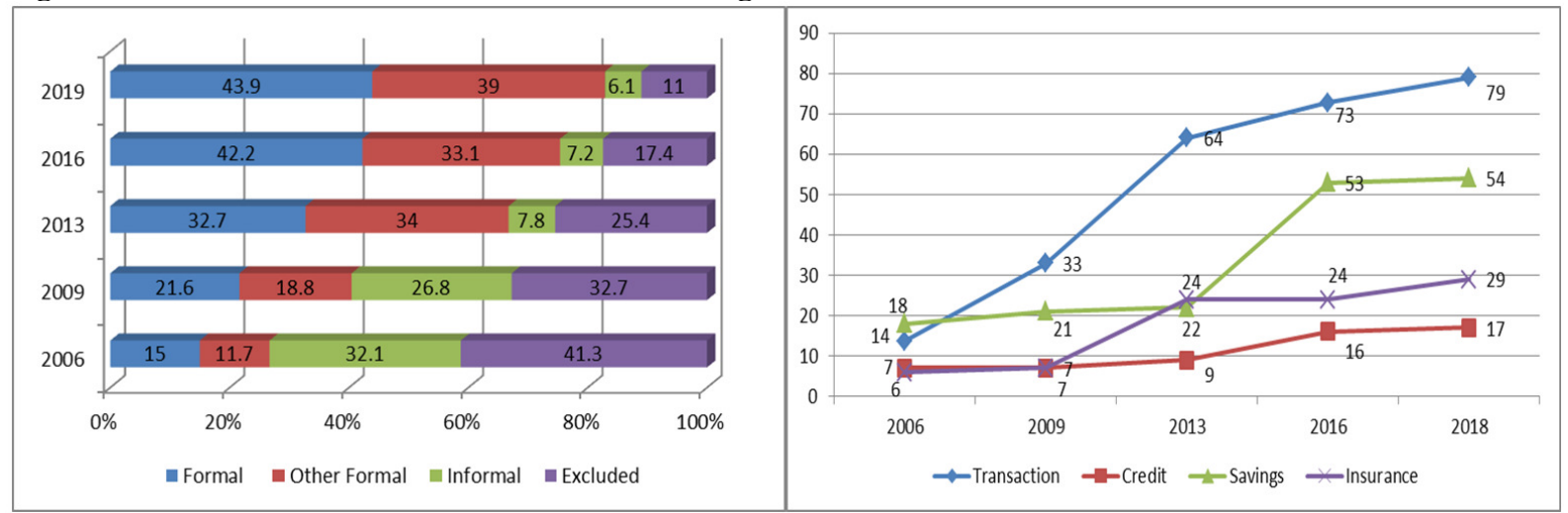

Source: FinAccess 2006, 2009, 2013, 2016 \& 2019

Formal financial usage increased sharply, rising from 27 percent in 2006 to 83 percent in 2019 driven by a surge in the uptake of mobile financial services (MFS) since 2007, introduction of Agency Banking in 2010, reduced information asymmetry following the sharing of credit information among other reasons. Both the informal and excluded strands contracted from a high of 32.8 percent and 41.3 percent in 2006 to 7.2 percent and 11 percent in 2019 respectively. Usage of financial services varies with individual preferences due to differences in the expected utility attached to each product. Transactionary product usage took the lion's share growing from 14 percent in 2006 to over 79 percent by 2019. This spike in the uptake of transactionary products is largely attributed to the adoption of mobile technology which triggered a revolution in the payments systems as people reduced their reliance on the traditional payment channels dominated by brick and mortar bank to the cash-lite, more convenient and modern payment platforms run through the mobile phone infrastructure. Usage of credit from formal access channels increased marginally even though the uptake remains at below 20 percent while savings uptake stood at 54 percent in 2019 up from 18 percent in 2006. Insurance product uptake rose from 6 percent in 2006 to 29 percent in 2019 with NHIF taking the lions share (Table 4.2).

\begin{tabular}{|c|c|c|c|c|c|c|}
\hline Usage & Product & 2006 & 2009 & 2013 & 2016 & 2019 \\
\hline \multirow{4}{*}{ Transactionary } & Current account with cheque book & - & 1.81 & 1.73 & 2.35 & 1.8 \\
\hline & Bank account without cheque book & 2.85 & 8.41 & 17.2 & 19.4 & 19.7 \\
\hline & ATM/Debit card & 7.32 & 11.8 & 19.65 & 22.05 & 20.2 \\
\hline & Mobile money account & - & 27.9 & 61.6 & 71.4 & 79.4 \\
\hline \multirow[t]{5}{*}{ Credit } & Personal Bank loan & 1.8 & 2.6 & 3.6 & 4.4 & 3.9 \\
\hline & DTS loan & - & - & 1.51 & 2.16 & 4.7 \\
\hline & Overdraft & 0.3 & 0.2 & 0.5 & 0.4 & 0.2 \\
\hline & Credit card & 0.8 & 0.8 & 1.8 & 1.2 & 0.5 \\
\hline & Mobile banking loan & - & - & - & 5.9 & 9.5 \\
\hline \multirow[t]{5}{*}{ Savings } & Bank savings account & 12.4 & 12.4 & 9.8 & 24 & 25.4 \\
\hline & DTS savings account & - & - & 2.85 & 3.18 & 10.9 \\
\hline & Postbank account & 5.6 & 2.5 & 2.3 & 1.5 & 0.3 \\
\hline & Investments & - & - & 11.6 & 10.3 & 3.2 \\
\hline & Mobile money & - & - & - & 43.3 & 53.6 \\
\hline \multirow[t]{8}{*}{ Insurance } & Car & 0.89 & 0.7 & 0.51 & 1.83 & 2.2 \\
\hline & House/Building & 0.05 & 0.07 & 0.02 & 0.36 & 0.1 \\
\hline & NHIF & - & 4.2 & 15.6 & 21.2 & 26.1 \\
\hline & Life & 2.03 & 0.62 & 0.09 & 1.27 & 1.1 \\
\hline & Private Medical & - & 0.97 & 0.39 & 2.11 & 2 \\
\hline & Education & 0.68 & 0.55 & 0.29 & 0.99 & 0.6 \\
\hline & Pension (excl. NSSF) & 0.55 & 1.14 & 0.85 & 0.39 & 1.3 \\
\hline & NSSF & 2.7 & 2.9 & 9.6 & 11.7 & 11.4 \\
\hline
\end{tabular}

Source: FinAccess 2006, 2009, 2013, 2016 \& 2019

Transactionary products were dominated by mobile money accounts whose uptake rose sharply from 28 percent in 2009 to 79 percent by 2019. This digital banking system has encroached into the traditional banking channels where ATM/Debit cards among other products used to dominate. Use of formal ATM/Debit cards averaged 20 percent by 2019 up from 7.32 percent in 2006. The spike in the uptake of mobile money accounts explains the speed at which households embrace financial innovations. Mobile money products are considered to be more convenient, affordable and highly accessible in comparison to the traditional banking services. Uptake of 
mobile banking products also peaked in the savings category courtesy of Safaricom's Mshwari, Airtel Money, Pesalink among other mobile bank products.

Credit product usage from the formal channel remains low in Kenya averaging 17 percent in 2019. The main contributor to credit uptake in 2019 was mobile bank loans (9.5) followed by loans from SACCOs (4.7) and Banks (3.9). Credit cards and overdraft facilities trailed at 0.5 percent and 0.2 percent respectively. This marks a shift in the uptake of credit products from the traditional formal banking products to the more easily accessible, convenient and more flexible mobile bank loans..

Savings product usage appeared to be on an upward trajectory by 2019. Although bank savings rose from 12.4 percent in 2006 to 25.4 percent in 2019 , mobile money savings rose from 43.3 percent in 2016 to 53.6 percent in 2019 boosting the gross savings. DTS savings are also on the rise standing at 10.9 percent up from 2.85 percent in 2013. Uptake of investment products from capital markets is falling averaging 3.2 percent in 2019 down from 10.6 percent in 2016 . The demand for savings appears to have shifted towards mobile savings accounts.

Usage of insurance and pension products remain low a marginal increase has been witnessed due to increasing government/employee funded medical schemes like the NHIF whose uptake in 2019 averaged 26 percent. Uptake of National Social Security Fund (NSSF) averaged 11.4 percent in 2019 accounting for the lions share in terms of pension products (Table 4.2).

\subsubsection{Disparities in Usage}

Although remarkable growth in financial inclusion has been reported at the national level, disparities in the uptake of financial services persist across different population segments. Fig 4.2 illustrates the disparities in the usage of financial services in Kenya using 2019 cross sectional survey data.

Fig 4.2: Disparities in Usage

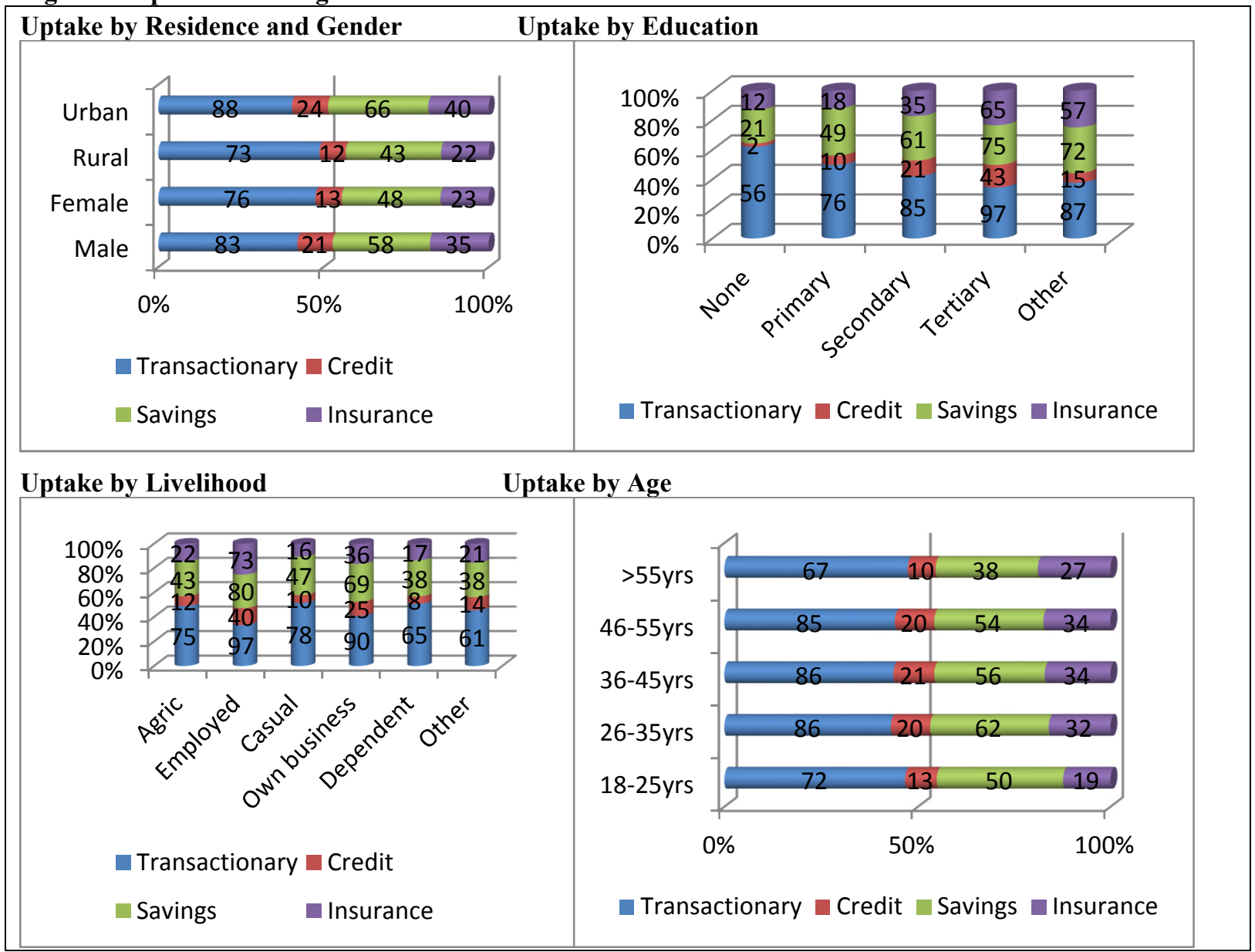

Source: Fin Access 2019

Although regional disparities in the uptake of financial services persist, FI has improved in both rural and urban areas averaging 73 percent and 88 percent respectively in 2019. This performance could be attributed to increased uptake of mobile financial services (MFS), which overcomes distance and difficult terrains to deliver services in remote areas. Mobile banking overcomes cream skimming due to the shared infrastructure by the creamy and non-creamy population segments in both rural and urban areas.

For example, male urban residents reported higher usage of the various financial products and services in 
2019. Usage of transactionary products was found to fall with education with the less educated accounting for the highest number of transactionary accounts. As the households approach tertiary level of education, there was a reduction in the transactionary accounts as they switched to credit savings and insurance products. Education mirrors uptake of formal financial services pointing to the central position held by human capital development on the financial sector. In terms of livelihood, casual workers accounted for the lions share in trasactionary product usage while the dependent population reported the least access to credit products. A quadratic relationship in terms of access to financial services was observed from the tabulation by age. Although the turning point for transactionary, credit and savings was around 36-45 years, savings peaked at 26-35 years. Figure 4.2 summarizes disparities in the usage of transactionary, credit, savings and investments and insurance and pension on the Kenyan population.

\subsection{Index of Financial Inclusion (IFI)}

Sarma (2008) formulae was employed in developing Kenya's IFI using cross sectional survey data on access and usage of financial services. Collins, Murdoch, Rutherford, and Ruthven (2009) argued that one's financial sophistication is evidenced by the number of financial instruments chosen rationally. An individual with more than one transactionary product, say, mobile money account and current bank account would be considered to be more financially included than one with just a single product. The disaggregated measure provides more accurate and reliable measure of the performance of the entire financial system and a ranking of sub regions often characterized by huge peculiarities.

Generation of the index from; transactionary, credit, savings and investment, insurance and pension followed Sarma (2008) three step process namely; normalization of indicators, decomposing the various products into their components and aggregation of the sub-indices. This was followed by a ranking of the sub regions based on the IFI score. This is represented in Fig 4.3 and Appendix Table 4.3.

\section{Fig 4.3: Index of FI (IFI)}

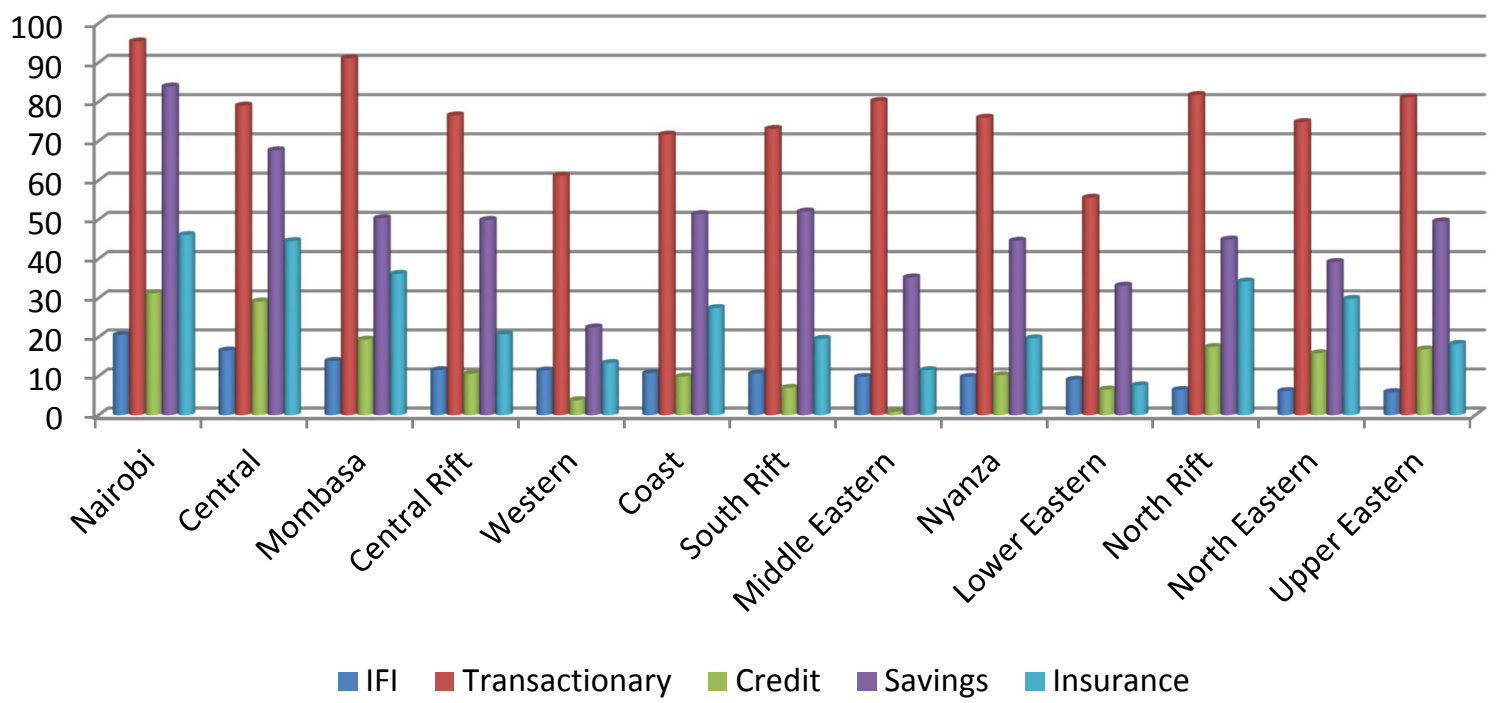

Source: Fin Access 2019

The mean FI aggregated for the entire financial system (transactionary, credit, savings and investments, insurance and pension) was found to be 11 percent in 2019 up from 7 percent in 2016. A ranking based on the IFI score placed Nairobi sub region first followed by Central and Mombasa sub regions in the second and third positions respectively. Upper Eastern trailed followed by North Eastern and North Rift in that order. The aggregated measure helps in measuring the performance of the financial system by giving insights on the level of financial sophistication based on the average number of financial services in the portfolio per region. It's however important to note that higher ranking based on the degree of sophistication does not necessarily translate to improved financial health. It could mean many things including holding dormant products in the portfolio. The single, transactionary, credit, savings and insurance measures, differ slightly from the IFI since they only represent the population reported to be using atleast one product per sub region. Nairobi dominated in all categories. Despite the low IFI score, Upper Easter reported significant usage of transactionary products (Figure 4.3).

A comparative analysis of 2016 and 2019 FinAccess survey data revealed a marked improvement in the level of financial sophistication across the sub regions (Appendix Table 4.3). This clearly confirms that defining FI on the basis of the degree of financial sophistication could be limiting. Conversely, defining FI in terms of holding atleast one formal financial product such as credit, transactionary, savings or insurance product could be too broad 
cloaking information on the specific nature of the formal product being held. This justifies a deeper interrogation of the components under each category of FI.

While most sub regions on average scored highly in terms of transactionary uptake, the low credit, savings and insurance scores reduced the overall performance significantly. Sub regions which reported high numbers of transactionary product usage performed better in aggregate terms.

\subsection{Needs Based Measure}

Marking a departure from the conventional measures of FI where respondents are asked questions on the financial products they currently use, ever used or never used, the needs based framework approaches FI from a use case perspective where respondents are first asked to identify needs that required financial management before they can identify the most suitable financial device. This issue is accorded a three pronged approach targeting; liquidity management tools, risk management tools and tools for managing future goals. This new approach explained using the 2019 cross sectional survey data provides interesting results.

\section{Figure 4.4: Liquidity Management}

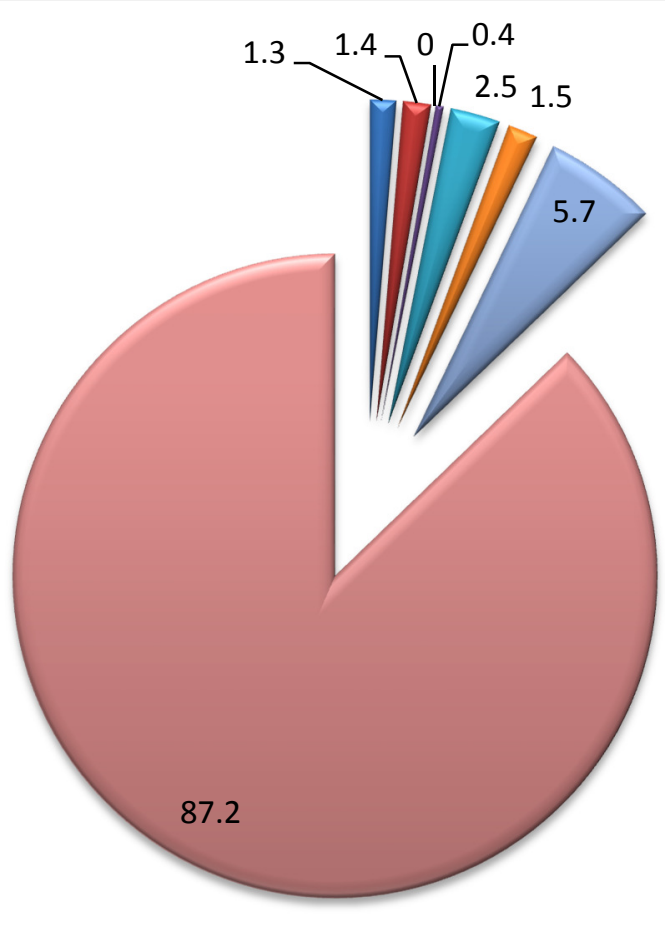

Credit from a bank / Sacco / microfinance

- Credit from mobile banking ((e.g. M-Shwari, KCB M-Pesa, M-Coop Cash, Eazzy Lo

$\square$ Credit from a Government institution

Borrowed from a digital appbased lender (e.g. Branch, Tala, Utunzi, KopaCredo,

$\square$ Used savings held at a bank / Post Bank / Sacco / microfinance

$\square$ Used savings held in mobile banking ((e.g. M-Shwari, KCB MPesa, M-Coop Cash, E

Figure 4.4 clearly shows that formal financial devices play an almost insignificant role in liquidity management accounting for only 12.8 percent. A majority therefore resort to non-formal solutions to manage their regular/day to day needs. 
Table 4.4: Risk Management

\begin{tabular}{|c|c|c|c|c|c|c|}
\hline & $\begin{array}{l}\text { Major } \\
\text { sickness/h } \\
\text { ealth } \\
\text { problem/a } \\
\text { ccident } \\
\text { injury }\end{array}$ & $\begin{array}{l}\text { Loss/damage of } \\
\text { business/livestock or } \\
\text { crop because of } \\
\text { natural or other } \\
\text { disasters }\end{array}$ & $\begin{array}{l}\text { Death of } \\
\text { main } \\
\text { income } \\
\text { earner }\end{array}$ & $\begin{array}{l}\text { Death of a } \\
\text { family } \\
\text { member or } \\
\text { other } \\
\text { relative }\end{array}$ & $\begin{array}{l}\text { Loss/damage of } \\
\text { major asset/ } \\
\text { money because } \\
\text { of theft,disaster } \\
\text { or other causes }\end{array}$ & $\begin{array}{l}\text { Child } \\
\text { birth }\end{array}$ \\
\hline $\begin{array}{l}\text { Credit from a } \\
\text { bank / Sacco / } \\
\text { microfinance }\end{array}$ & ㄱos & (2) & (2) & 0.3 & 2.5 & 1.6 \\
\hline $\begin{array}{l}\text { Credit from } \\
\text { mobile banking }\end{array}$ & 0.1 & 0.3 & 0 & 0 & 0.6 & 0 \\
\hline $\begin{array}{l}\text { Digital App } \\
\text { Loan }\end{array}$ & 0.1 & 0 & 0 & 0 & 0 & 0 \\
\hline $\begin{array}{l}\text { Savings at a } \\
\text { bank / Post } \\
\text { Bank / Sacco / } \\
\text { microfinance }\end{array}$ & 9.1 & 10 & 6.5 & 8.3 & 12.9 & 7.6 \\
\hline $\begin{array}{l}\text { Savings from } \\
\text { mobile banking }\end{array}$ & 1.3 & 1.6 & 2.4 & 1.1 & 5.6 & 2.5 \\
\hline $\begin{array}{l}\text { Savings with a } \\
\text { mobile money } \\
\text { provider }\end{array}$ & 5.8 & 6.4 & 0 & 4.4 & 11.7 & 4.1 \\
\hline $\begin{array}{l}\text { Claimed } \\
\text { insurance }\end{array}$ & 4.5 & 0 & 1.6 & 0.8 & 0 & 7.6 \\
\hline Non formal & 77.1 & 81.1 & 89.5 & 85.1 & 66.7 & 76.6 \\
\hline
\end{tabular}

Source: Author, 2019

Similar to the case of liquidity management, reliance on formal solutions to manage risks was put to question from the reported figures. From the main shocks listed, respondents appeared to rely more on non-formal solutions. Savings with a mobile money provider was however the most preferred tool among all formal financial solutions. Figure 4.5 Looking into the Future

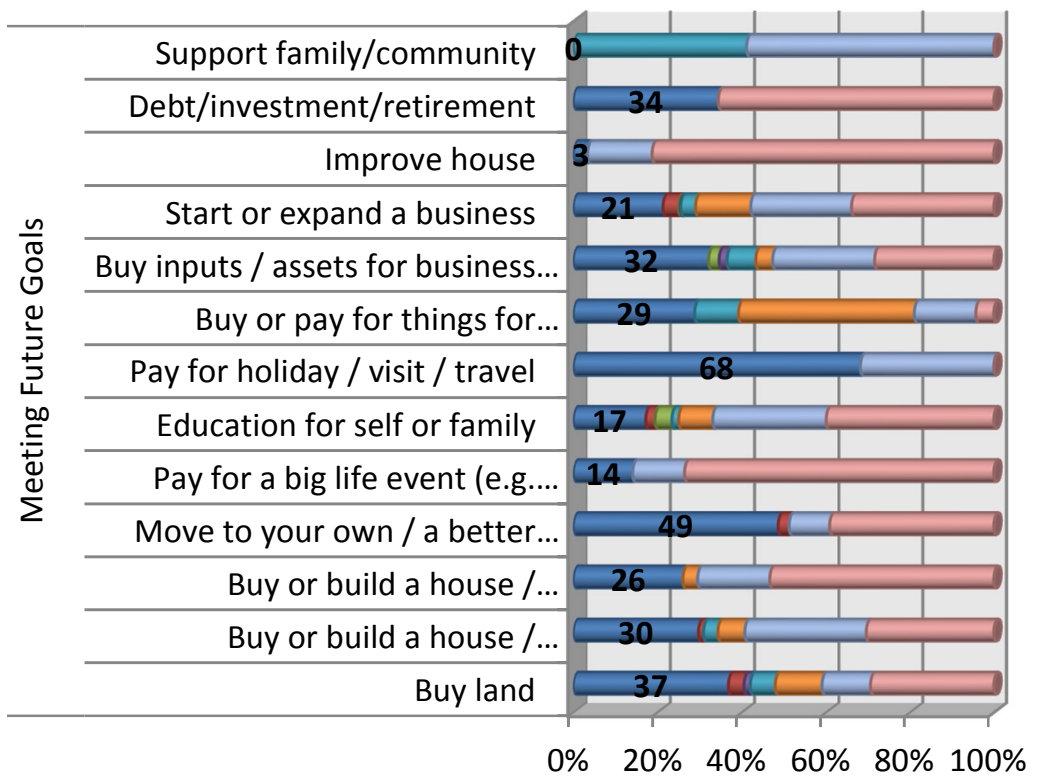

Credit from a bank / Sacco / microfinance

Credit from mobile banking

Borrowed from a Government institution

Digital App Loan

Savings at bank /Post Bank/Sacco/MFI

$\square$ Savings in mobile banking

$\square$ Savings in a mobile money provider / wallet

$\square$ Non formal

Source: Author, 2019

Figure 4.5 focused on devices used to manage long term future goals held by the respondents. The study established that households leverage on credit from banks, saccos and microfinance institutions to plan for their future. This is supplemented by savings in a mobile money provider or wallet. Despite this, non formal solutions remain largely bullish. 


\subsection{Stochastic Dominance Tests of FI}

This section presents stochastic dominance test results based on the various approaches to create better understanding. Fig 4.6 represents the GL curve for the transactionary, credit, savings and insurance product usage to illustrate the stochastic dominance across the various sub regions.

\section{Fig 4.6: Generalized Lorenz curves}
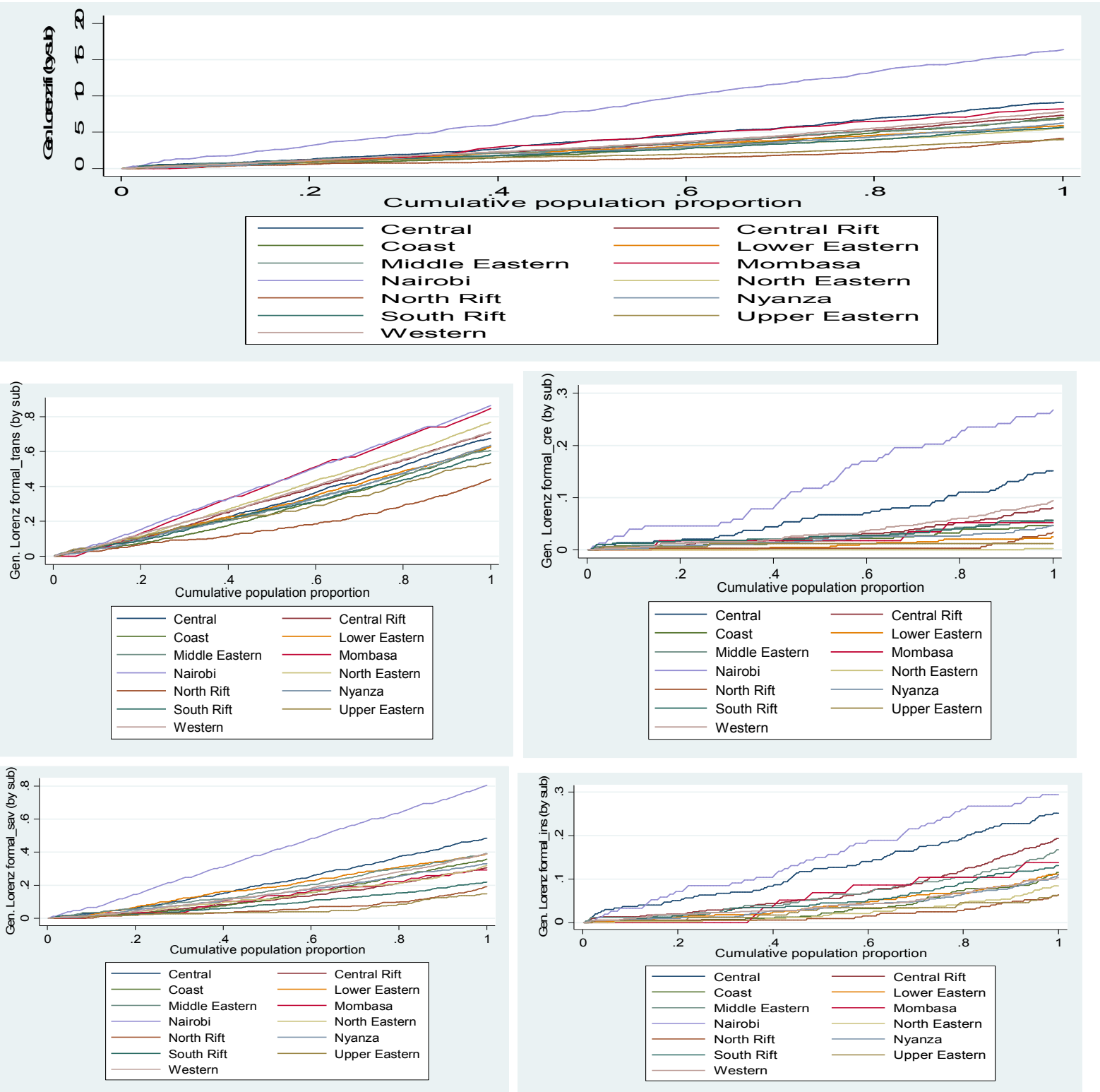

Source: Author, 2019

Figure 4.6 revealed huge disparities in the dominance structure of formal financial products across the sub regions. In all the categories, Nairobi region appear to dominate in terms of the IFI meaning that Residents of Nairobi sub region are more financially sophisticated as compared to the other sub regions. In terms of transactionary product usage, both Nairobi and Mombasa dominate other regions. The gap widens between Nairobi and the sub regions as we approach the 100 percent cumulative population. To test the dominance along different population segments, the Two-sample Kolmogorov-Smirnov test for equality of distribution functions was used.

\section{Table 4.5: Two-sample Kolmogorov-Smirnov test for equality of distribution functions}

\begin{tabular}{|c|r|r|r|}
\hline Smaller group & D & P-value & Corrected \\
\hline Rural: & 0.1172 & 0 & \\
\hline Urban: & 0 & 1 & \\
\hline Combined K-S & 0.1172 & 0 & 0 \\
\hline
\end{tabular}

Source: Author, 2019

The stochastic dominance technique by Levy (1998) tests whether both groups were sampled from populations with identical distribution. The P-value for the rural group in Table 4.3 shows that the population may 
differ in median, variance or the distribution. Where there is crisscrossing of the cumulative distributions for the various population segments, a second order stochastic dominance test has to be conducted to bring out the differences.

\section{Conclusions and Policy Implications}

The objective of this paper was to develop a reliable measure of FI based on cross-sectional data. The FinAccess household survey data provides information on the developments in the financial sector and the status of uptake of financial products and services from the demand side. The information reported is based on the five waves of Fin Access surveys, 2006, 2009, 2013, 2016 and 2019. The study established that there is a large variation in the uptake of the various categories of FI products with transactionary products taking the lions share (79 percent) followed by savings and investment (53 percent), insurance ( 29 percent) and credit (17 percent) in that order. The disparity is also evident along the different sub regions where Nairobi, Central and Mombasa sub regions ranked highest according to the index of financial inclusion (IFI) as compared to the rest of the country. Upper Eastern, North Eastern and North Rift trailed the other sub regions on the basis of IFI rankings. In terms of regional uptake, out of the seven regions considered, Eastern region trailed in the usage of formal financial services hence stochastically dominated by all other regions. Nairobi region which is predominantly urban was ranked highest. This could be rationalized by the proximity of the urban population to financial access channels.

The study findings signaled a paradigm shift from the over reliance on traditional transactionary banking products such as debit/ ATM cards, bank accounts among others to the more flexible and readily accessible mobile money accounts. Policy change to accommodate mobile financial services led to a revolution in the financial sector leading to deepened financial markets. A similar picture was observed in the uptake of savings following the amendment of the SACCO Act that brought in DTS savings which appear to be encroaching into the market for traditional bank savings and investments to increase its market share. The same picture is reflected in the use of credit products where the market for bank loans is slowly being taken up by mobile bank loans. But even with the introduction of new products, savings and credit usage has remained low since 2006 and more particularly among the rural populace.

Gender disparities persist in the uptake of financial products since 2006. The FI distribution of the male gender stochastically dominates the female distribution across all financial products. The distribution of the urban cluster also dominates usage of the more flexible mobile financial products as compared to the distribution of the rural population. The distribution of insurance services on the other hand is stochastically dominated by NHIF and NSSF products which take the lions share. In all the categories of formal product usage, that is; transactionary, credit, savings and insurance, the distribution for tertiary education to a large extent appear to stochastically dominate the other education levels.

Given the sharp focus accorded on the access and usage of financial inclusion in this paper, it will be interesting to see how the impact and quality dimensions of FI plays out in future. The study also recommends the use of a needs based approach to establish use case in the measurement of financial inclusion.

\section{References}

Abdel-Magid, M. F. (1979). Toward a Better Understanding of the Role of Measurement in Accounting. The Accounting Review, 54, No. 2.

Aduda, J. \& Kalunda, E. (2012). Financial Inclusion and Financial Sector Stability with reference to Kenya. Journal of Applied Finance and Banking, 2 (6), 95-120

Alliance for Financial Inclusion (2011). The G20 Principles for Innovative Financial Inclusion: Bringing the Principles to Life. Case Studies Prepared on behalf of the Global Partnership for Financial Inclusion. Bangkok

Alliance for Financial Inclusion (2011). Measuring Financial Inclusion: Core Set of Financial Inclusion Indicators Report. Bangkok, Thailand

Amidzic, G., Massara, A., \& Mialou, A. (2014). Assessing Countries Financial Inclusion Standing: A New Composite Index. IMF Working Papers, 14(36), 1

Beck, T., Demirgüç-Kunt, A., \& Maksimovic, V. (2005). Financial and Legal Constraints to Growth: Does Firm Size Matter? The Journal of Finance, 60(1), 137-177

Beck, T., Demirgüç-Kunt, A., \& Levine, R. (2007). Finance, inequality and the poor. Journal of Economic Growth J Econ Growth, 12(1), 27-49

Campbell, N., \& Thorndike, A. M. (1953). What is Science? Phys. Today Physics Today, 6(8), 18

Central Bank of Kenya, Kenya National Bureau of Statistics \& Financial Sector Deepening Kenya (2019). FinAccess Household Survey. Nairobi, Kenya

Central Bank of Kenya, Kenya National Bureau of Statistics \& Financial Sector Deepening Kenya (2016). FinAccess Household Survey. Nairobi, Kenya

Central Bank of Kenya, Kenya National Bureau of Statistics \& Financial Sector Deepening Kenya (2013). FinAccess Household Survey. Nairobi, Kenya 
Central Bank of Kenya, Kenya National Bureau of Statistics \& Financial Sector Deepening Kenya (2009). The 2016 FinAccess Household Survey on financial inclusion. Nairobi, Kenya

Central Bank of Kenya, Kenya National Bureau of Statistics \& Financial Sector Deepening Kenya (2006). The 2016 FinAccess Household Survey on financial inclusion. Nairobi, Kenya

Chakravarty, S. R., \& Pal, R. (2013). Financial inclusion in India: An axiomatic approach. Journal of Policy Modeling, 35(5), 813-837

Chakravarty, K.C., (2011). Financial Inclusion and Banks: Issues and Perspectives: Address delivered at the FICCI - UNDP Seminar on "Financial Inclusion: Partnership between Banks, MFIs and Communities. New Delhi

Claessens, S. (2006). Access to Financial Services: A Review of the Issues and Public Policy Objectives. The World Bank Research Observer, 21(2), 207-240

Collins, D., Morduch, J., Rutherford, S. and Ruthven, O. (2009). Portfolios of the Poor: How the World's Poor Live on \$2 a Day. Princeton, New Jersey: Princeton University Press. 320 pp. \$29.95. ISBN 06-91141-48-7 (HB). Journal of South Asian Development, 5(2), 306-309

Deaton, A. (1986). Chapter 30 Demand analysis. Handbook of Econometrics, 1767-1839

Demirguc-Kunt, A., Klapper, L., Singer, D., \& Oudheusden, P. V. (2015). The Global Findex Database 2014: Measuring Financial Inclusion around the World. Policy Research Working Paper, No. 7255, World Bank, Washington, DC

Demirgüç-Kunt, A., \& Klapper, L. (2012). Financial Inclusion in Africa: An Overview. Policy Research Working Paper, No. 6088. Washington, D.C.: World Bank

Demirguc-Kunt, A., Klapper, L., \& Singer, D. (2013). Financial Inclusion and Legal Discrimination against Women: Evidence from Developing Countries. Policy Research Working Paper, No. 6416. Washington, D.C.: World Bank

DFID (2004). The importance of financial sector development for growth and poverty reduction, Working Paper series, London, UK.

Financial Sector Deepening (2011). Highlights from FSD's strategy 2011-2015: Issue 06

Financial Sector Deepening Trust (2014). Supporting the development of inclusive financial markets. Annual Report

Global Partnership for Financial Inclusion (2011). Financial Inclusion Data: Assessing the landscape and country level target approaches. Discussion paper, IFC, Washington, DC

Greenwood, J., \& Jovanovic, B. (1990). Financial Development, Growth, and the Distribution of Income. Journal of Political Economy, $98(5$ 1), 1076-1107

Greenwood, R., \& Scharfstein, D. (2013). The Growth of Finance. Journal of Economic Perspectives, 27(2), 3-28

Hannig, A., \& Jansen, S. (2010). Financial Inclusion and Financial Stability: Current Policy Issues. Working Paper, No. 259. Tokyo: Asian Development Bank Institute

Honohan, P. (2005). Banking Sector Crises And Inequality. Policy Research Working Paper, No. 3659.

Honohan, P. (2008). Cross-country variation in household access to financial services. Journal of Banking \& Finance, 32(11), 2493-2500

International Monetary Fund (2012). Financial Access Survey, Statistics Department

Lindbeck, A. and D. J. Snower (2001, Winter). Insiders and outsiders. Journal of Economic Perspectives 15 (1), $165-188$

Mas-Colell, A., Whinston, M.D., and Green, J.R. (1995). Microeconomic Theory. Oxford University Press, New York Oxford.

Mckenzie, D. J. (2004). Asymptotic theory for heterogeneous dynamic pseudo- panels. Journal of Econometrics, 120(2), 235-262

Meng, Y., Brennan, A., Purshouse, R., Hill-Mcmanus, D., Angus, C., Holmes, J., and Meier, P. S. (2014). Estimation of own and cross price elasticities of alcohol demand in the UK - A pseudo-panel approach using the Living Costs and Food Survey 2001-2009. Journal of Health Economics, 34, 96- 103

Merton, Robert C., and Zvi Bodie. (1995). A Conceptual Framework for Analyzing the Financial Environment. Chap. 1 in The Global Financial System: A Functional Perspective, edited by Dwight B. Crane et al. Cambridge: Harvard Business School Press

Philippon, T. (2015). Has the US Finance Industry Become Less Efficient? On the Theory and Measurement of Financial Intermediation. American Economic Review, 105(4), 1408- 1438

Porta, R. L., Lopez - De - Silanes, F., Shleifer, A., \& Vishny, R. (1998). Law and Finance. Journal of Political Economy, 106(6), 1113-1155

Porta, R. L., Lopez-De-Silanes, F., Shleifer, A., \& Vishny, R. W. (1997). Legal Determinants of External Finance. The Journal of Finance, 52(3), 1131-1150

Rajan, R., \& Zingales, L. (1998). Financial Dependence and Growth. American Economic Review, 88(3), 559-586.

Raza, S. H., Shahzadi, H., \& Akram, M. (2014). Exploring the Determinants of Financial Development (Using Panel Data on Developed and Developing Countries). Journal of Finance and Economics, 2(5), 166-172 
Sarma, M., \& Pais, J. (2010). Financial Inclusion and Development. Journal of International Development, 23(5), 613-628

Sarma, M. (2008). Index of Financial Inclusion A Concept Note, ICRIER Working paper No. 215. Indian Council for Research in International Economic Relations, New Delhi

Sarma, M. (2012). Index of Financial Inclusion. A measure of financial sector inclusiveness. Berlin Working Papers on Money, Finance, Trade and Development, Working Paper No. 07

Sen, A. (1981). Poverty and Famines: An Essay on Entitlement and Deprivation, Oxford: Clarendon Press.

Shorrocks, A. F. (1983). Ranking Income Distributions. Economica, 50(197), 3-17

Stevens, S. S. (1959). Measurement, Psychophysics and Utility in C. W. Churchman and P. Ratoosh (eds.), Measurement Definitions and Theories, John Wiley.

Woolcock, M. (2013). Social Inclusion: Its significance for Development Theory

World Bank (2008). Finance for all?: policies and pitfalls in expanding access. The International Bank for Reconstruction and Development. Washington D.C.

World Bank (2014). Access to finance. An unfinished agenda. The International Bank for Reconstruction and Development. Washington D.C.

World Bank (2015). South Africa Economic Update. South Africa

World Bank (2015). Global Monitoring Report, 2015/2016

\section{Appendix}

Table 4.1: FI correlation matrix a) $\mathbf{2 0 1 6}$

\begin{tabular}{|l|r|r|r|r|r|r|r|}
\hline \multicolumn{1}{|c|}{2016} & \multicolumn{1}{l|}{ IFI } & \multicolumn{1}{l|}{ Savings } & Transactionary & Credit & Insurance & Formal & Informal \\
\hline IFI & 1 & & & & & & \\
\hline Savings & 0.6935 & 1 & & & & & \\
\hline Transactionary & 0.6366 & 0.4424 & 1 & & & & \\
\hline Credit & 0.5657 & 0.227 & 0.1724 & 1 & & & \\
\hline Insurance & 0.4936 & 0.164 & 0.157 & 0.2149 & 1 & & \\
\hline Formal & 0.6272 & 0.4833 & 0.913 & 0.1732 & 0.2586 & & 1 \\
\hline Informal & 0.1708 & 0.173 & 0.214 & 0.0538 & 0.0352 & 0.2026 & 1 \\
\hline
\end{tabular}

b) 2019

\begin{tabular}{|l|r|r|r|r|r|r|r|}
\hline \multicolumn{1}{|c|}{2016} & \multicolumn{1}{|l|}{ IFI } & \multicolumn{1}{l|}{ Savings } & Transactionary & Credit & Insurance & Formal & Informal \\
\hline IFI & 1 & & & & & & \\
\hline Savings & 0.6387 & 1 & & & & & \\
\hline Transactionary & 0.6073 & 0.403 & 1 & & & & \\
\hline Credit & 0.6704 & 0.3363 & 0.2492 & 1 & & & \\
\hline Insurance & 0.6835 & 0.3394 & 0.3088 & 0.3662 & 1 & & \\
\hline Formal & 0.6008 & 0.4415 & 0.9455 & 0.2582 & 0.3414 & & 1 \\
\hline Informal & 0.3224 & 0.5475 & 0.2279 & 0.1398 & 0.1341 & 0.2342 & 1 \\
\hline
\end{tabular}

Table 4.3: 2019 Index of FI (IFI) Ranking

\begin{tabular}{|r|l|r|r|r|r|r|r|r|r|r|r|}
\hline & \multicolumn{2}{|c|}{ IFI (\%) } & \multicolumn{2}{c|}{ Transactionary (\%) } & \multicolumn{2}{c|}{ Credit (\%) } & \multicolumn{2}{|c|}{ Savings (\%) } & \multicolumn{2}{c|}{ Insurance (\%) } \\
\hline & Sub Region & $\mathbf{2 0 1 6}$ & $\mathbf{2 0 1 9}$ & $\mathbf{2 0 1 6}$ & $\mathbf{2 0 1 9}$ & $\mathbf{2 0 1 6}$ & $\mathbf{2 0 1 9}$ & $\mathbf{2 0 1 6}$ & $\mathbf{2 0 1 9}$ & $\mathbf{2 0 1 6}$ & $\mathbf{2 0 1 9}$ \\
\hline 1 & Nairobi & 16 & 21 & 93 & 95 & 26 & 31 & 72 & 84 & 43 & 46 \\
\hline 2 & Central & 9 & 17 & 84 & 79 & 19 & 29 & 67 & 68 & 33 & 45 \\
\hline 3 & Mombasa & 8 & 14 & 85 & 91 & 18 & 19 & 56 & 50 & 32 & 36 \\
\hline 4 & Central Rift & 7 & 12 & 76 & 77 & 16 & 11 & 49 & 50 & 24 & 21 \\
\hline 5 & Western & 8 & 11 & 69 & 61 & 12 & 4 & 50 & 22 & 15 & 13 \\
\hline 6 & Coast & 7 & 11 & 62 & 72 & 12 & 10 & 37 & 51 & 18 & 27 \\
\hline 7 & South Rift & 6 & 11 & 73 & 73 & 18 & 7 & 54 & 52 & 28 & 20 \\
\hline 8 & Middle Eastern & 7 & 10 & 73 & 80 & 12 & 1 & 47 & 35 & 24 & 12 \\
\hline 9 & Nyanza & 6 & 10 & 68 & 76 & 13 & 10 & 53 & 45 & 20 & 20 \\
\hline 10 & Lower Eastern & 6 & 9 & 74 & 56 & 15 & 7 & 62 & 33 & 18 & 8 \\
\hline 11 & North Rift & 4 & 6 & 46 & 82 & 10 & 17 & 28 & 45 & 15 & 34 \\
\hline 12 & North Eastern & 6 & 6 & 23 & 75 & 1 & 16 & 4 & 39 & 4 & 30 \\
\hline 13 & Upper Eastern & 4 & 6 & 60 & 81 & 6 & 17 & 25 & 50 & 15 & 18 \\
\hline
\end{tabular}

Note: Unweighted data 